\title{
MANAGERIAL COMPETENCIES AND SUCCESSION IN FAMILY FIRMS
}

\author{
Piotr Bartkowiak ${ }^{1}$
}

DOI: https://doi.org/10.31410/LIMEN.S.P.2019.9

\begin{abstract}
The effectiveness of an organisation determined a host of factors which are inextricably linked to its resources and environment. The ever-increasing pace of change affects both what is inside and outside an organisation. This changes the way organisations are managed as their actions become ever more complex endeavours that often require changes in approaches. This is also true for family-owned firms ${ }^{2}$ whose founder's (or founders') intention was not just to create temporary jobs and earning opportunities for their families but also to ensure stable succession and, thereby, the "longevity" of their family enterprise. Continued duration and growth of family business depends on how effective the transfer of knowledge, competencies, powers and ownership is. Unless the founder recognises this early enough in the process, they will be harming their organisations. The study attempts to explain the essence and significance of managerial and successor competences in a family business, and presents a model of professional competences for managers as determinants of the development of family businesses.
\end{abstract}

Keywords: Efficiency, Effectiveness, Developing competences.

\section{INTRODUCTION}

$\mathrm{H}_{\mathrm{i}}$ ow a business is run will change dynamically depending on how turbulent the conditions in which it operates become (Trocki, Grucza \& Ogonek, 2009, p. 11). Family firms are often the "backbone" of the national economy. Without them, technological progress and all manner of innovations would be substantially limited. W. Orłowski notes that there are few large corporations in market economies that would not have originated from a dynamic family-run business. Conversely, there is an untapped potential for growth in every dynamic, innovative and well-managed family firm. If one were to ask about what it is that distinguishes a family business from a large corporation the most, there could only be one answer: an individual.

\section{FAMILY FIRM FOUNDER'S MANAGERIAL COMPETENCIES AS A FACTOR IN EFFECTIVE SUCCESSION}

Experience shows that ensuring effective succession in a family business for two or three generations is not at all an easy task. The odds that a family firm will survive long enough for it to transition to the next generation are not too good: only about thirty percent of family businesses make it to the second generation, and just ten percent make it to a third (Fleming, 2006, p. 8). While there are many different reasons why business transitions fail, they are mostly related to insufficient planning and the missing arrangements for who will take responsibility for the firm and what this responsibility involves.

Poznań University of Economics and Business; Department of Investment and Real Estate; Al. Niepodległości 10; 61-875 Poznań, Poland

2 A family firm is a business entity in which ownership or management control is vested in the hands of the members of a single family and which involves more than one family member in its operations. 
While the market offers a widespread and practically limitless supply of all traditional resources you might need to run a family business (tangible assets, workforce, information, finance), there is one asset that cannot be bought ready-made, namely managerial and organisational competencies. They are the synergistic outcome of knowledge, skills, experience, personal traits, attitudes and behaviours of all employees in an organisation.

\section{MANAGERIAL COMPETENCIES}

The concept of competencies provides an answer to one of the fundamental questions posed by scholars of entrepreneurship: Why is it that only some people can see and realise the opportunities coming up in their environment that allow them to become very effective.

Building a competitive position involves competency management. A review of literature on the subject shows that knowledge, skills, attitudes, personal traits, experience and behaviours are the most often cited elements of competencies. The term "competency" is multifaceted, which makes it hard to classify and define it. While they have made numerous attempts at reconciling their positions, scholars are still not unanimous about its meaning. As noted by G. Filipowicz, virtually every author comes up with their own definition and tries to justify it in some way or other (Filipowicz, 2004, p. 17). This is not so much because of some defect or limitation in how that concept can be used in practice, but rather reflects a pragmatic attitude in which effectiveness trumps theoretical considerations. It is worth noting that management science saw the term appearing at the time human capital began to rise in importance.

Against this general background, the definition proposed in this study is as follows: managerial competencies represent the managers' ability to utilise necessary knowledge, skills, personal traits, experiences, motivations, attitudes and behaviours to attain any such objectives, results or standards as may expected of them in their specific job. All of these components are meant to ensure effective performance of any tasks in an ever-evolving environment.

Modern theories of management highlight the role of knowledge and skills in effective organisational performance. Knowledge and skills have come to be viewed as a source of competitive advantage and, as such, as a core organisational resource. It is for this reason, too, that employee development is in greater focus now as a means of increasing both personal competencies of employees (knowledge and skills) and those of an organisation as a whole.

\section{EFFECTIVENESS AS A BASIC DIMENSION OF A MANAGER'S WORK}

P. Drucker considers effectiveness the most important aspect in analysing the executive's role (Drucker, 1994). According to S. Banaszak, effectiveness is the ability to take decisions of great importance to the organisation (Banaszak, 2006, p. 20).

Every action - whether by an organisation, a team or an individual - is taken in specific conditions and inherently involves some expenditure to reach its objective. In evaluating an action, one should therefore consider its efficiency (sprawność) and effectiveness (skuteczność) and the performance of the actor/entity involved as a fundamental dimension of praxeology (Strzoda, 2005 , p. 9). Therefore, the manager's work involves deciding on the direction and quality of work, both of which are of enormous importance to the entire organisation and its performance and achievements (Banaszak, 2006, p. 20). 
The effectiveness of action ex post is the relationship between the results or outcomes of some action and the expenditure that was needed to achieve them. Effectiveness ex ante, on the other hand, is defined as the relationship between the objectives of action and the anticipated means needed to achieve them (Pszczołowski, 1978, p. 60). Praxeology, which is the study of efficient action, provides the most universal definition of effectiveness, highlighting its essential components, such as efficacy (a degree to which the intended goal has been achieved) and economy understood as the cost of achieving the goal (the amount of work, funds and time expended). In this context, some scholars distinguish between performance and effectiveness in management. P. Drucker argues that a manager's performance can be evaluated in terms of two concepts: efficiency and effectiveness (Stoner, et al, 2001, p. 29). The way Drucker understands those terms, efficiency means "doing things right", while effectiveness is the ability to set proper goals (Bartkowiak, 2002, p. 95), or "doing the right things" (Stoner, et al, 2001, p. 29). According to Stoner, Freeman and Gilbert, performance is a measure of a manager's efficiency and effectiveness, or a measure of the extent to which managers can set and achieve proper goals (Stoner, et al, 2001, p. 23). People working in organisations and those who manage them are assumed to act rationally - that is to say, in their decision-making they are guided by whatever goals have been set and they strive to achieve them with a minimum of expenditure involved.

Following M. Bielski, one could say that, in this sense, evaluating effectiveness/performance is about the degree to which the desired objectives have been attained, and then about the degree to which the available resources have been used (Bielski, 1997, p. 104). K. Obuchowski, in turn, suggests that effective human action means going beyond certain ad-hoc requirements, that is to say, beyond one's ability to carry out routine day-to-day tasks (Obuchowski, 1997, p. 21). Obuchowski also notes that effectiveness is a measure of one's capacity to complete future tasks, or in other words, tasks that are unspecified and unknown. T. Majewski notes that, under praxeological approach, every action that is viewed as positive is effective (Majewski, 2005, p. 88). According to Majewski, such action might be expressed with such terms of efficiency as efficacy, economy, accuracy, cleanliness, soundness, or simplicity. Tadeusz Kotarbiński, on the other hand, claims that action is effective when its leads to the result intended as its objective (Kotarbiński, 1958, p. 116).

Effectiveness, therefore, is a gradable concept - one that is measured by the degree of goal attainment. Actions can be fully effective, partially effective, ineffective (when we did not move even by an inch towards our goal) or counter-effective (when not only did we not inch any closer to our goal, but we in fact moved even further away from it) (Kieżun, 1978, p. 28). In analysing the issue of effectiveness, one must mention P. Drucker, whose view was that managerial effectiveness cannot be associated with any innate predisposition or a specific personality type (Drucker, 1994, p. 122). According to P. Drucker, “...there is no effective personality. The effective people I have seen differ widely in their temperaments and their abilities, in what they do and how they do it, in their personalities, their knowledge, their interests". For W. Krzeszowski, this means that whether or not a manager is effective does not depend on their personality traits, but rather on the conditions they operate in (Krzeszowski, 2005, p. 39). Understood this way, the issue boils down to tracking down the sources of effectiveness: whether they are inherent in the manager or their environment.

Numerous other terms have been used to discuss effectiveness, such as economy, productivity, profitability, performance, or efficacy, to name a few based on a review of the literature. In comparing those terms, authors usually do not determine their scopes in relation to each other. 
According to T. Majewski, effectiveness can be expressed by different forms of efficiency (Majewski, 2005, p. 88). W. Kieżun, in turn, claims that the core values of efficient action (efficient here equals effective), i.e. action that prevents chaos and disorder and is measured by entropy, are its efficacy, usefulness and economy (Kieżun, 1998, p. 18). According to Kieżun, there are also other (additionally significant) forms of efficiency, namely cleanliness, accuracy and reliability. One should note the clear indecision regarding the relationship among efficacy, effectiveness and efficiency. T. Kotarbiński confirms this when he says: What is interesting is the relationship in which efficacy stands to effectiveness, namely whether efficacy is just a particular case of effectiveness or not. Now, if effectiveness is merely a degree of goal attainment and does not include any effects that are useful but were not part of the goal, then efficacy is not just a particular case of effectiveness, for efficacy pertains not just to the intended effects but, more generally, to any effects that occurred as a consequence, irrespective of whether someone intended them to occur or not, as long as they are positive and not negative. (Kotarbiński, 2003, p. 576). According to A. Szpaderski, what efficacy and effectiveness have in common is that both of them are oriented towards the result of action. In short, the difference is that effectiveness is about attaining the intended goal, whereas efficacy is about attaining positive results with no condition being imposed that such results must be as intended in view of the goal of action (Szpaderski, 2005, p. 43).

\section{SHAPING AN EFFECTIVE SUCCESSOR'S COMPETENCIES}

In general terms, based on T. Majewski's formula (Majewski, 2006, p. 55), the effectiveness of a successor's (manager's) action is a function of three factors, namely: general operating conditions, motivation, and competencies. According to R. Walkowiak, what determines the effectiveness of a manager's or successor's actions are their competencies (Walkowiak, 2004, p. 90). This relationship can be illustrated using R. Walkowiak's own effectiveness-competency function matrix (Fig. 1).

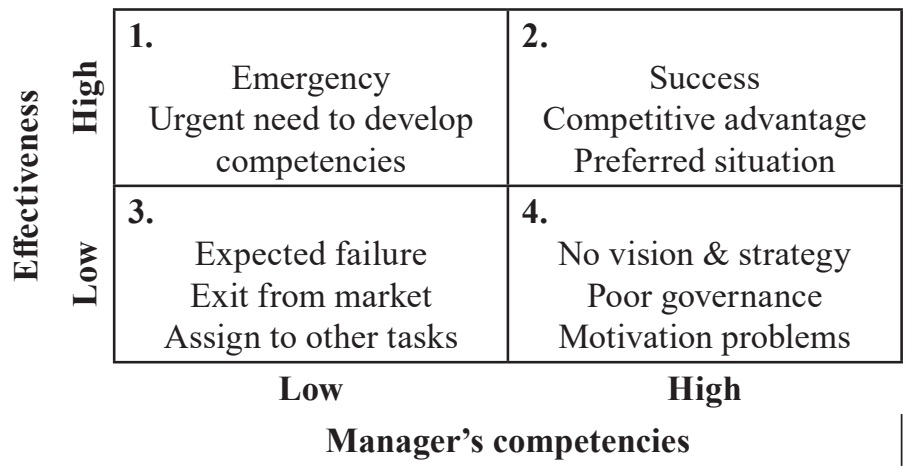

Figure 1. Effectiveness-competency matrix

Source: Own compilation based on (Walkowiak, 2004, p. 92 \& Majewski, 2006, p. 57)

The missing link between the manager's competencies and effectiveness (first quadrant) could be explained by luck, some fortuitous circumstance or a large effort on the part of subordinates. In the fourth quadrant, the explanation could be poor motivation. The situation in which competencies are low but effectiveness is high is most common after some technological change. High effectiveness in the immediate period after such change is due mostly to the experience and involvement of managers who need their competencies bolstered, including by participation in training (Walkowiak, 2004, p. 93). Where the manager's competencies are high but effectiveness is low (fourth quadrant), this might imply poor governance. The reasons could be inappropriate organisational vision and strategy, both of which should determine what appropriate competencies are. Situations in which 
there is a link between competencies and work results (performance) are a more frequent occurrence, however. The most desirable arrangement is one where both competencies and work results are high (second quadrant). Low competencies translating to poor work results (third quadrant) should lead one to consider the need for a manager's professional development or replacement. In their manager's competency matrix, A. Gick, M. Tarczyńska (Gick \& Tarczyńska, 1999, p. 45) and R. Walkowiak (Walkowiak, 2004, p. 92) distinguish four possible situations:

1. High competencies - high effectiveness (organisation enjoys a strong market position);

2. High competencies - low effectiveness;

3. Low competencies - high effectiveness;

4. Low competencies - low effectiveness (the need should be considered for a manager's professional development or replacement).

According to T. Majewski, the more a specific job competency profile is aligned with the tasks to be carried out on that job and the closer the manager's competency profile is to the requirements of their position, the more effectively the relevant tasks will be carried out (Majewski, 2006, p. 58). That said, the authors believe that competencies are just one of the conditions for managerial success. High competencies that are aligned with the requirements of a specific job or role within the organisation foster high effectiveness (Walkowiak, 2004, p. 93). It should be borne in mind, however, that maintaining high effectiveness in the long run requires a concern for continuous and systematic improvement of managerial competencies.

\section{AN EFFECTIVE MANAGER/SUCCESSOR IN A FAMILY FIRM. A MODEL}

The interdisciplinary nature of human resource management, including competency management, poses some difficulties in selecting the scientific methods to be used in describing the problem under consideration. Empirical research often uses (directly or with some modifications) scientific methods and tools that have been tried and tested in other studies. This is true for this study, although in selecting the method and tools I have followed my own methodology. I have developed my theoretical model (a list of 52 competencies) based on the following:

- the sales manager's tasks, responsibilities, duties and authority;

- the competency model for effective managers as described in the literature;

- the profile of the $20^{\text {th }}$ century manager;

- National Standards for Professional Qualifications.

As part of this study, a list of competencies has been compiled with an appendix defining each of those competencies. They were sent to a group of 180 purposely selected managers (owners) representing family-run businesses. The goal of this survey was to verify if relevant competencies were chosen and to limit their number on that basis. The respondents were asked to identify 15 competencies they believed were most important for their successor to have. To mark their significance, the effective manager's competencies were listed in descending order of importance.

Based on the survey, two business competencies are thought to be of key importance for an effective and efficient manager/successor to have in a family-run business, namely identifying client needs and sales planning and development, with more than $60 \%$ of the managers selecting those competencies. Other important base competencies include resilience to stress $(49 \%$ of responses) and client acquisition skills ( $43 \%$ of responses). Other significant factors affecting managerial effectiveness are the ability to organise and conduct business meetings, the ability to pitch offers and client orientation. These competencies were indicated by every third respond- 
ent. Out of these 52 competencies (divided into three groups of bases, professional and social competencies), I have selected 18 (Table 1) which have the greatest influence on how effectively and efficiently a manager/successor in a family firm acts. The competencies in this model were operationalised using the ABC analysis, which is based on the Pareto principle (20/80 rule) stating that approx. $20 \%$ of items in any given set represent approx. $80 \%$ of the cumulative value of a feature or attribute for which the set is being examined. The assumption here is that key competencies come from a subset representing $20 \%$ of the entire competency set.

Table 1. Competencies of an effective and efficient manager/successor in a family firm

\begin{tabular}{|c|c|}
\hline \multirow{7}{*}{ Business competencies } & Sales planning and development \\
\hline & Identifying client needs \\
\hline & Resilience to stress \\
\hline & Customer acquisition \\
\hline & Conducts business meetings \\
\hline & Client orientation \\
\hline & Presentation skills \\
\hline \multirow{6}{*}{ Professional competencies } & Product knowledge \\
\hline & Relationship building \\
\hline & Market analysis \\
\hline & Decision-making \\
\hline & Collaborative attitude \\
\hline & Ability to act effectively \\
\hline \multirow{5}{*}{ Social competencies } & Negotiation skills \\
\hline & Communication skills \\
\hline & Ability to delegate authority and tasks \\
\hline & Motivation \\
\hline & Conflict resolution skills \\
\hline
\end{tabular}

Source: Bartkowiak, Niewiadomski, 2012, p. 21

The survey shows that, out of all the competencies concerned, communication skills, ability to create relationships and product knowledge are among those of utmost importance for the manager/successor in a family firm to do their work both effectively and efficiently. Negotiation skills and ability to acquire customers come up high in the ranking, too. Based on how the sales managers ranked the most important competencies from the three groups, one may conclude that efficient managerial action is determined by a number of varied and multifaceted skills. As shown above, competencies are not differentiated in terms of their importance, the underlying assumption being that each one of them is very important and that each of them should be reflected in whatever an effective manager/successor in a family firm does in practice. The model is not static and closed, because there is no way of predicting all organisational behaviours or what happens in its environment, even in the most immediate future.

\section{CONCLUSION}

Most businesses and employees today vie for success as their goal. Attaining success requires far-reaching changes and willingness to change. The source of success is good management one that extends not only to technologies but also people. Increasing effectiveness in bridging the competency gap is therefore a new challenge for numerous managers/successors in family-run businesses. For that reason, the competency model proposed here might be of interest to those who seek to boost the strategic performance of their family firms. 
The way it was built, the model shows the individual competencies as correlated, mutually pervading and supplementary. The selected competencies are not fixed categories; the model was designed with a view to being modified and augmented according to needs. We can realise how difficult it is to compile lists and that individual researchers create their broad lists of competencies which are not ranked and are given different names and interpretations. Also, dividing competencies into different subsets is always a matter of convention and depends on what the particular authors or institutions need. In this study, such a division was made to show the internal structure of competencies.

The issues raised here require further, and deeper, exploration. What is proposed here should be treated as working hypotheses subject to further elaboration. In conclusion, an effective manager/successor in a family firm might be said to be someone with competencies that allow them to act efficiently and effectively, or to put it in other words, someone who is both "doing the right things" and "doing things right" (Drucker, 1994, p. 33).

\section{REFERENCES}

Banaszak, S. (2006). Menedżerowie w strukturze społecznej. Poznań: University of Communications and Management.

Bartkowiak, G. (2002). Skuteczny kierownik - model i jego empiryczna weryfikacja. Poznań: Poznań University of Economics and Business.

Bartkowiak, P. \& Niewiadomski, P. (2012). Efektywne zarządzanie firmą rodzinną - kompetencyjne wyzwania sukcesji. In T. Dudycz, G. Osbert-Pociecha \& B. Brycz (Eds.) Efektywność - konceptualizacja i uwarunkowania. (pp. 11-24). Wrocław: Research Papers of Wrocław University of Economics No 262.

Bielski, M. (1997). Organizacje, istota, struktury, procesy. Łódź: University of Lodz.

Drucker, P.F. (1994). Menedżer skuteczny. Kraków: Cracow University of Economics.

Filipowicz, G. (2004). Zarzadzanie kompetencjami zawodowymi. Warszawa: PWE.

Fleming, Q.J. (2006). Tajniki przetrwania firmy rodzinnej: jak uniknąć siedmiu grzechów głównych niszczących firmy. Gliwice: Helion.

Gick, A. \& Tarczyńska, M. (1999). Motywowanie pracowników. Warszawa: PWE.

Kieżun, W. (1978). Bariery sprawności organizacji. Warszawa: PWE.

Kotarbiński, T. (2003). Niektóre zagadnienia epistemologii pragmatycznej. In T. Kotarbiński (Ed.), Dzieła wszystkie. Prakseologia, cz. II, (pp. 572-577). Wrocław: Ossolineum Publishing House.

Kotarbiński, T. (1958). Traktat o dobrej robocie. Wrocław-Warszawa: Ossolineum Publishing House.

Krzeszowski, W. (2005). Cechy kierownika (dowódcy), a jego efektywność. In J. Michniak (Ed.), Efektywność kierowania (dowodzenia). Materials from the symposium, National Defence Academy, Warszawa, February 15, 2005 (pp. 39-42). Faculty of Management and Command.

Machnik, A. (2002). Sekrety sprawnego działania. Warszawa: Studio EMKA.

Majewski, T. (2005). Wymiary efektywności działania kierownika (dowódcy). In J. Michniak (Ed.), Efektywność kierowania (dowodzenia). Materials from the symposium, National Defence Academy, Warszawa, February 15, 2005 (pp. 87-94). Faculty of Management and Command.

Majewski, T. (2006). Kompetencje dowódcze oficerów wojsk lądowych sił zbrojnych RP. Warszawa: National Defence Academy. 
Obuchowski, K. (1997). Przez galaktykę potrzeb. Poznań: Zysk i S-ka.

Pszczołowski, T. (1978). Mała encyklopedia prakseologii i teorii organizacji. Wrocław: Ossolineum Publishing House.

Stoner, J.A.F., Freeman, R.E. \& Gilbert, D.R. (2001). Kierowanie. Warszawa: PWE.

Strzoda, M. (2005). Efektywność - istota, znaczenie, zakres pojęciowy. In J. Michniak (Ed.), Efektywność kierowania (dowodzenia). Materials from the symposium, National Defence Academy, Warszawa, February 15, 2005 (pp. 9-24). Faculty of Management and Command.

Szpaderski, A. (2005). Problemy efektywności działań w teorii organizacji i zarządzania i sugestie ich rozwiązania w duchu prakseologii. In J. Michniak (Ed.), Efektywność kierowania (dowodzenia). Materials from the symposium, National Defence Academy, Warszawa, February 15, 2005 (pp. 43-53). Faculty of Management and Command.

Trocki, M., Grucza, B. \& Ogonek, K. (2009). Zarzadzanie projektami. Warszawa: PWE.

Walkowiak, R. (2004). Model kompetencji menedżerów organizacji samorząowych. Olsztyn: University of Warmia and Mazury in Olsztyn. 